\title{
Obituary
}

\section{Ralph Millard, Jr., M.D.}

Ralph Millard died quietly in bed at his home in Aventura, Florida, on a Sunday morning, several weeks after his $92^{\text {nd }}$ birthday. He will be listed as among the best, if not the best, American Plastic Surgeons of the $20^{\text {th }}$ century.

His father was an attorney in St. Louis, and David Ralph Millard, Jr. was born in Barnes Hospital, where he would return years later to (briefly) train in Plastic Surgery under James Barrett Brown.

The family moved to Asheville, North Carolina, where Ralph graduated from Asheville School for Boys. He went on to Yale University, where he was on the football and boxing teams, and he remained passionate about these two sports for the rest of his life. After graduating from Yale in 1941, he went on to graduate from the accelerated wartime program at Harvard Medical School in 1944, and then spent a year of internship at Boston Children's Hospital. Following this limited surgical training, he served in the Navy from 1945-46. After decommissioning from the Navy, he spent a year as a surgical resident at Vanderbilt University. Beverly Douglas invited Harold Gilles to Vanderbilt where Ralph was able to meet him, and obtain permission to become a trainee at Gillies' unit at Basingstoke, where he remained from 1948 to

\begin{tabular}{|l|l|}
\hline \multicolumn{2}{|c|}{ Access this article online } \\
\hline Quick Response Code: & \\
\hline
\end{tabular}

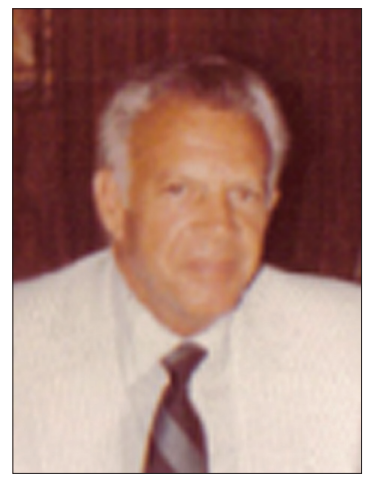

D. Ralph Millard

June 4, 1919-June 19, 2011
1949. During this time in England, Ralph visited all of the other important plastic surgeons in the UK such as T. Pomfret Kilner at Oxford (where he learned cleft palate repair), Archibald McInoe, and others, and was able to visit Victor Veau in Paris several weeks before his death. He also became fast friends with other trainees who were with Gillies at the time, such as Jack Mustardé, Hugo Obwegeser, and Ivo Pitanguay.

Following his time in Europe, he managed to find a position in Plastic Surgery at Barnes Hospital, under James Barrett Brown, Louis T. Byars and Frank McDowell. This year of training was cut short when, apparently, Dr. Brown became annoyed at the young Millard repeatedly pointing out that Gilles would have done differently. The remainder of the year was spent as a cosmetic fellow with Clair Straith in Detroit, who had a busy rhinoplasty practice, and following this, still needing a year more residency for his Boards, Ralph was the first Plastic Surgery resident in the new program at Baylor.

Having now finished all of his plastic surgery training in the US, Ralph returned in 1952 to work with the now Sir Harold Gillies on their book; apparently Gillies at the time was much more interested in his golf or fly fishing, but Millard persevered. Both of them saw humor where others might not, and the book was written in a way new to medical writing. One well-known Boston surgeon reviewed the book for a publisher and said that it should never be printed, but finally Little, Brown and Co. (that was to publish all of Millard's subsequent books) took the book, and it was published as The Principles and Art of Plastic Surgery in 1957. Gillies in his 1920 book, Plastic 
Surgery of the Face, had listed a few basic principles, and these were expanded to 16 in Principles and Art. Throughout the remainder of his career as a teacher of plastic surgery, Millard dwelt on the importance of these principles, which he expanded to become an overall philosophy of life. A plastic surgeon should carry himself (Millard never had a female resident, although there were a number of female fellows) in a certain fashion, and when one resident stomped into a room and sat down with a crash, he was told, "Dick, that wasn't very Plastic."

After finished the book with Gillies, Ralph, having spent only one year in the Navy during WW II, found himself recalled to active duty, this time in the US Marine Corps. Before he was sent to Korea, he met Barbara Smith, his future wife, in San Diego. While he was in Korea, Barbara returned home to Tulsa, Oklahoma, where she hosted a television program.

Millard's year in Korea is legendary. There was a lull in the fighting, and he developed an active reconstructive surgery service, caring for Korean soldiers from both sides of the conflict. A picture taken at the time shows a long line of patients with tube pedicles waiting to be seen by Millard. He also told the story of his conception of the rotation advancement procedure; he was looking at a picture of a patient with a cleft which he had placed up on an easel, and as he was dozing off, he said he had an "ah ha moment" where he visualized the procedure, and then marked on the picture the incision lines for the rotation-advancement repair. Another story, perhaps embellished, is that he found his first patient for the procedure in a rice field, and captured him with a lasso, having learned a number of rope tricks during his time in Houston.

With Gillies' help, Millard was able to get his paper on the rotation advancement on the program of the $1^{\text {st }}$ International Congress of the International Society of Plastic Surgeons in Stockholm, in 1955. Having been given only 5 minutes for the paper, Millard started speaking at the back of the large hall, walking to the podium where he then used his 5 minutes.

After his second decommission from the Military in 1955, Millard married Barbara Smith, and briefly went into practice in Beverly Hills, California.

In 1956 the Millards moved to Miami. Finding himself frozen out of the cleft team by local politics, Millard began making regular trips to the Bahamas and Jamaica, where he continued to make improvements on his rotation advancement procedure. Between 1956 and 1966, Millard published a number of pioneering papers on cleft lip repair, nasal reconstruction, rhinoplasty, and facelifting with in-continuity submental lipectomy.

In 1967 Millard took over the newly opened residency program at the University of Miami on a "temporary" basis, since he was not a geographic full-time employee. He remained Chief of the Division for the next 25 years, training 176 residents and fellows, of whom an impressive number have become leaders in plastic surgery in the United States and abroad (presidencies of The American Association of Plastic Surgeons, The American Society of Plastic and Reconstructive Surgeons, The American Society of Maxillofacial Surgeons, The International Society of Plastic Surgeons (2), Chairmen of The American Board of Plastic Surgery, and The European Board of Plastic, and the European Association of Plastic Surgeons. ) Dr. Millard took an intense interest in his trainees, and at times the scrutiny was difficult to bear. However, virtually everyone who trained with him appreciated his insistence on excellence, and The Millard Society was founded a few decades ago.

Besides having great technical skills and a constantly innovative mind, Millard was an accomplished medical writer. Besides The Art and Science of Plastic Surgery, coauthored with Sir Harold Gillies, he was the sole author of the three volume CleftCraft, The Principalization of Plastic Surgery, and A Tetralogy of Rhinoplasty. His autobiography, Saving Faces, was published in 2003, three years after his retirement. Aside from his work in cleft lip and palate, which established him as the ultimate authority in this area, he made many contributions in nasal reconstruction, and was responsible for getting Gary Burget and Fred Menick to carry on the torch in this area. He was one of the first to undertake breast reconstruction in the early 1970's, using tube pedicles to obtain results which would hold their own against contemporary methods (except in number of procedures). He also was one of the first to perform primary jaw reconstruction at the time of ablative surgery, and there were numerous other contributions to the area of reconstructive surgery, published mostly in Plastic and Reconstructive Surgery, all beautifully illustrated, and written in his unique style.

He was also an acknowledged master of aesthetic surgery, and made many contributions to the areas of 
facelift and rhinoplasty. Aesthetic patients, if they wanted to be operated on by Millard, would be done at Jackson Memorial Hospital (a county hospital providing the bulk of indigent care in Miami) along with his reconstructive patients. He was the plastic surgeons' plastic surgeon, the one to take your wife or child to if they needed either aesthetic or reconstructive surgery.

Millard served as a Director of The American Board of Plastic Surgery, was President of the Educational Foundation of The American Society of Plastic and Reconstructive Surgery, and of The American Association of Plastic Surgeons. He received Honorary Fellowships of the Royal College of Surgeons both in Edinburgh and England.

After being in practice with him for 25 years, I finally asked him for a signed picture. He wrote on it, cryptically," Tony, Plastic Surgery is not as easy as it seems!" I am not sure whether he meant it wouldn't be as easy for others with lesser skills than his, or if one set the bar as high as he did, it would be hard to match, or one would have to deal with difficult patients....or perhaps all of the above.

There were 16 principles listed in Gillies and Millard, expanded to 32 in Principalization of Plastic Surgery. Principal number 8 was "Know the Ideal Beautiful Normal", and I think was Millard's favorite. He, more than anyone of his era, was able to achieve it.

\section{Addendum}

It was a sad task for me to write the obituary for Ralph Millard, who had been my teacher and then associate for 25 years. It had been a happy task several months earlier for me to accept an invitation to come to India in 2012 to deliver The Millard Oration to the Indian Society of Cleft Lip and Palate and Craniofacial Anomalies. Now it will be of greater importance than ever for me to give a proper summation of the many contributions to Plastic Surgery made by Ralph Millard, particularly in the area of cleft lip and palate surgery.

(Some of Dr. Millard's books have been digitized, and along with his autobiography can be obtained on at MillardSociety@aol.com)

\section{S. Anthony Wolfe \\ Chief, Division of Plastic Surgery, Miami Children's Hospital, 3100 S.W. 62nd Avenue, Suite 2230, \\ Miami, Florida 33155 \\ Address for Correspondence Dr. S. Anthony Wolfe, Miami Children's Hospital,3100 S.W. $62^{\text {nd }}$ Avenue, \\ Suite 2230, Miami, Florida 33155 \\ E-mail: awolfemd@bellsouth.net}

How to cite this article: Wolfe SA. D. Ralph Millard, Jr., M.D.. Indian J Plast Surg 2011;44:371-3.

Source of Support: Nil, Conflict of Interest: None declared. 